S. Afr. J. Agric. Ext.

Vol. 44, No. 2, 2016: 30 - 41

DOI: http://dx.doi.org/10.17159/2413-3221/2016/v44n2a377

Manenzhe, Zwane

\& van Niekerk.

(Copyright)

\title{
FACTORS AFFECTING SUSTAINABILITY OF LAND REFORM PROJECTS IN EHLANZENI DISTRICT MPUMALANGA PROVINCE, SOUTH AFRICA
}

\author{
Manenzhe $^{4}$, T. D., Zwane ${ }^{5}$ E. M. \& van Niekerk ${ }^{6}$, J. A. \\ Correspondence Email: tebogo.manenzhe@gmail.com
}

\begin{abstract}
The study evaluated factors affecting sustainability of land reform projects in Mpumalanga Province in Bushbuckridge Local Municipality (BLM) of Ehlanzeni District. The study was conducted between July and September 2014. A random sampling technique was used in selecting 31 key informants from the projects. Data were collected using face-to-face interviews with key informants that had benefited from the projects using a questionnaire administered as an interview schedule. Data collected were analysed using SPSS. The results shows that both males and females were well represented (50\% males) and (50\% females), $42 \%$ of participants are above 50 years, $83 \%$ does not have farming skills, $42 \%$ had formal education up to High school level, $75 \%$ received agricultural training. Training improved project performance (67\%), sustainability (67\%), enhanced job creation (58\%) and boosted project profitability (92\%). 67\% received post training support, 92\% received training through top down approach. The most factors affecting projects sustainability are lack of government support (75\%), failure to receive training on time (75\%), and complicated bureaucracy in accessing training (67\%).
\end{abstract}

Keywords: Land Reform Projects, Sustainability, Beneficiaries, Agricultural Training, Extension Implications, Ehlanzeni District, South Africa.

\section{INTRODUCTION}

In South Africa, the legacy of apartheid was not just the inequality in access to resources such as land, but uncertain economy that by 1994 had been through negative growth and left the majority of the population in poverty (Sparks 2003). The country has conceived land reform as a significant role player in boosting economic growth and alleviating poverty. World Bank and other advisors in South Africa in the early nineties argued for a far-reaching land reform programme on these grounds (Greenberg 2003). The need for land reform to address the legacy of the past was clearly identified in the new South African Constitution (Act 108 of 1996, Section 25). The Reconstruction and Development programme (RDP) identified land reform as a key component of its programmes of meeting basic needs and building the economy (ANC 1994). The White Paper on South African Land Policy included in its strategic goals the promotion of economic growth and poverty reduction through land reform (DLA 1997).

The South African land reform programme, developed by the African National Congress (ANC) government that won the first democratic elections in 1994, consists of three main programmes: redistribution, restitution and tenure reform. This study focused on restitution.

\footnotetext{
${ }^{4}$ Advisor at Department of Rural Development and Land Reform in Mpumalanga.

${ }^{5}$ Research Affiliate at Centre for Agriculture, Rural Development and Extension. University of the Free State, P O Box 68, University of the Free State, Bloemfontein, South Africa.

${ }^{6}$ Director of Centre for Agriculture, Rural Development and Extension. University of the Free State, P O Box 68, University of the Free State, Bloemfontein, South Africa.
} 
S. Afr. J. Agric. Ext.

Vol. 44, No. 2, 2016: 30 - 41

DOI: http://dx.doi.org/10.17159/2413-3221/2016/v44n2a377
Manenzhe, Zwane

\& van Niekerk.

(Copyright)

Restitution is of particular interest as it is an integral part of the broader land reform programme and closely linked to the need for the redistribution of land and tenure reform. The White Paper on South African Land Policy stipulated that restitution beneficiaries would be given priority treatment in State supported development programme (DLA 1997).

This paper draws its inputs from a study which was conducted in Ehlanzeni District between July and September 2014 which evaluated factors affecting sustainability of land reform projects in Mpumalanga Province in Bushbuckridge Local Municipality (BLM). However this paper seeks to achieve the following objectives:

- To identify factors affecting sustainability of land reform projects in Mpumalanga Province.

- To determine beneficiary's feelings regarding the level of project sustainability, limitations; and discover beneficiary's willingness in their projects.

\section{THEORETICAL BACKGROUND}

Many countries have conceived and implemented land reform programmes; the South African programme of land reform is believed to be an important strategy for rural economic growth, food security and poverty reduction. In order for land reform to rise to the occasion where it will be reckoned as a force for change in the lives of many people, it needs to be sustainable for the future generations. This view is held by many authors, for instance, Jacobs (2003), has argued that land reform beneficiaries must be able to improve their livelihoods and deal with other challenges afflicting rural areas such as high unemployment, poverty and dilapidated infrastructure. With regard to sustainability, Dumanski (1994) showed that there is substantial evidence that sustainability of agricultural projects may contribute significantly to resolving many major problems facing rural people such as poor rural economy and poverty.

Another notable author (Walters, undated) agreed that there are challenges regarding land reform improving the lives of many citizens, especially when they consider past experiences since the dawn of democracy in South Africa. The sentiment is that the South African land reform experience has largely failed to produce sustainable farms and farmers. He further indicated that at least $73 \%$ of restituted farmlands was unproductive, delivering neither foods or jobs. This has been true and senior people from the government have agreed that the sustainability of land reform projects in South Africa is low. Thus, land reform policy in South Africa is being readjusted to ensure that land reform projects are sustainable.

It is clear that South Africa, like many of world's developing countries has goals of achieving sustainable development. Thus, it is also seeking to achieve these goals through its land reform projects. This study is intended to examine factors affecting sustainability of these projects. Having said that, this section examines some of the commonly used connotations and definitions of the concept "sustainable" and "sustainable agriculture" in particular. The idea is to arrive at a commonly acceptable definition that is easy to understand and use.

The terms "sustainable" and "sustainability" are subjective and value loaded concepts and hence, there is no consensus to their meaning. The terms are used differently in diverse contexts. The terms basically mean 'able to ensure food production security without sacrificing the long term health of the ecosystem and vital resources that makes food production possible' (Giovannucci, Scherr, Nierenberg, Heberbrand, Shapiro, Milder \& Wheeler, 2012: 7). When applied to projects, it therefore means maintaining or upholding 
S. Afr. J. Agric. Ext.

Vol. 44, No. 2, 2016: 30 - 41

DOI: http://dx.doi.org/10.17159/2413-3221/2016/v44n2a377
Manenzhe, Zwane

\& van Niekerk.

(Copyright)

their potential production. Generally speaking, the terms sustainable and sustainability implies to change that is beneficial. Since what is regarded beneficial is different for different people, especially when considering the variables time, place and cultural milieu, a universally acceptable definition of sustainable and sustainability is highly improbable. According to Sustainability Store (1999), sustainable or sustainability is conceptualised as a vector set of beneficial farming practices, which does not decrease overtime. Following below is a summary of some views of what sustainability can encompass:

The International Fund for Agricultural Development (IFAD) (2006) gave the following description of a sustainable project-: "is sustained in the medium or even longer term without continued external assistance, the project net worth is constantly going up, debt is consistently going down, farm enterprise is consistently profitable from year to year, production increases from season to season and reliance on government support is decreasing". The above description of how IFAD conceptualises sustainability has informed IFAD Strategic Framework 2007-2010 (IFAD, 2007) to formulate the following description-: "ensuring that the organization is supported through projects and the benefits realized are maintained and continue after the end of the project".

These days, sustainable agriculture has become a slogan. According to the World Commission on Environmental and Development (WECD, 1987), sustainable farming is "farming that meets the needs of present without compromising the ability of future generations to meet their own needs". The description underscores the need for society to ensure intergenerational equity in the sense that the present generation does not consume so much as to foreclose the option of the future generations to enjoy at least the present level of consumption and wellbeing.

Sustainable land reform projects are projects that have efficient production of safe, high quality agricultural products, in a way that protects and improves the natural environment, the social and economic conditions of farmers, their employees and local communities and safeguards the health and welfare of all farmed species. Furthermore, sustaining land reform projects means: ensuring agricultural productivity and maximizing economic development while protecting natural resources from depletion and degradation to the detriment of our future generation.

Nkwinti (2013) indicated that the government would establish District Land Reform Committees, as proposed in the NDP, to contribute to, and accelerate, sustainable land reform projects. According to Nkwinti, (2013), the government introduced the Recapitalisation and Development Programme (RADP), which serves to provide emerging farmers with a range of support packages, in terms of inputs, strategic support and infrastructure. Going forward, the government will establish the Rural Cooperatives Finance Facility (Rucoff), to provide much needed financial and other technical support to a fledgling class of small-holder farmers and co-operatives in both commercial and communal land spaces and procured from them so that they could grow and be sustainable. This background has brought the questions on factors affecting sustainability of the land reform projects.

\section{RESEARCH METHODOLOGY}

The study was conducted between July and September 2014 in Mpumalanga Province in Bushbuckridge Local Municipality (BLM) of Ehlanzeni District Municipality (EDM) which is located in the north-eastern part of Mpumalanga Province. According to EDM (2014), the 
S. Afr. J. Agric. Ext.

Vol. 44, No. 2, 2016: 30 - 41

DOI: http://dx.doi.org/10.17159/2413-3221/2016/v44n2a377
Manenzhe, Zwane

\& van Niekerk.

(Copyright)

district shares boarders with Mozambique and Swaziland in the east, Gert Sibande District in the south, Mopani and Sekhukhune Districts of Limpopo in the north and Nkangala District Municipality in the west. It is comprised of five local municipalities namely: Mbombela, Umjindi, Bushbuckridge, Nkomazi and Thaba Chewu. However, Bushbuckridge Local Municipality (BLM) is located in the north-eastern part the Mpumalanga province of South Africa. The municipality is one of the two constituents of the former Bohlabela District Municipality.

This study investigated factors affecting sustainability of land reform projects in Mpumalanga Province. The approach adopted was a case study in which it focused on Restitution land reform projects. The advantage of a case study is that it engages comprehensive situation unlike random model (Bulmer \& Warwick, 1983).

In-depth interviews with people (key informants) who know what is going on in the given study projects were conducted too. The purpose was to collect data from people who are knowledgeable and directly engaged in the farming activities within the given study. These informants with their knowledge and understanding provided insight on the nature of factors affecting sustainability of their projects and gave recommendations for possible solutions.

Key informants with first-hand information about the study were selected carefully. Face-toface interviews were used. A total of 31 key informants were interviewed. Informants were selected from the following organizations and groups: 12 current Communal Property Association (CPA) committee members, nine replaced CPA committee members, nine inactive community members from different households, Provincial Land Reform Office and Provincial Department of Agriculture. Furthermore, focus group was used to verify and test the reliability of the data collected. In addition, focus group discussions were used as one of the qualitative methods of verifying, testing the validity of the data collected and ideas of the group. A focus grouped was classically informants forming part of the current CPA committee.

In order to make sense of data, SPSS program was used to perform data entry and analysis in frequencies and percentages to ease the data interpretation. It can be indicated that the researcher observed the requirements for transparency and ethics when collecting the data. The importance of confidentiality in keeping and publishing of the research information was clearly explained to each participant hence no pressure was exerted to anybody to participate.

\section{RESULTS AND DISCUSSION}

\subsection{Personal characteristics respondents}

Oladele (2011) noted that it was a wide belief that males are dominating agricultural sector as compared to female. The personal characteristics of respondents are presented in Table 1. 
S. Afr. J. Agric. Ext.

Vol. 44, No. 2, 2016: 30 - 41

DOI: http://dx.doi.org/10.17159/2413-3221/2016/v44n2a377

Table 1: Personal characteristics of respondents

\begin{tabular}{|l|c|c|}
\hline Variable & Frequency & Percentage \\
\hline Gender & & \\
\hline Male & 6 & 50.0 \\
\hline Female & 6 & 50.0 \\
\hline Age Distribution & & \\
\hline $30-35$ & 1 & 8.3 \\
\hline $36-40$ & 2 & 16.7 \\
\hline $41-45$ & 1 & 8.3 \\
\hline $46-50$ & 3 & 25 \\
\hline Older & 5 & 41.7 \\
\hline Previous Occupation & & \\
\hline General Farm Worker & 2 & 17.0 \\
\hline None & 10 & 83.0 \\
\hline Highest Qualification & & \\
\hline Primary School & 3 & 25.0 \\
\hline Secondary School & 5 & 42.0 \\
\hline Diploma & 4 & 33.0 \\
\hline
\end{tabular}

According to Table 1, 50\% were males while the other $50 \%$ were females. There is a wide belief recorded by Oladele (2011), that males are more dominant in agricultural activities as compared to the females. This shows that both males and females were well represented in this study. Although as far as the age of farmers is concerned, Van Reenen \& Marais (2013) found that farmer's age influences a few things such as; attitudes, risks and uncertainties to undertake farming. A younger, progressive farmer has a lot to gain by tackling a high risk undertaking.

However, the older, more established farmer has a great deal to lose and relatively little to gain in relation to what the assets he already owns. It was found that the majority of respondents was older than 50 years and constitutes $41.7 \%$ of the respondents.

\subsubsection{Farming skills}

The business of farmers is to farm. Effective farming needs someone involved in farming to possess different skills sets. Farmers were asked whether they are knowledgeable in farming. The majority of the respondents $83 \%$ interviewed were previously not involved in farming as an occupation. They are currently involved in farming, while only $17 \%$ were previously involved. In this case farming skills were not as good as one would expect due to lack of training.

\subsubsection{Formal education}

The role of formal education in sustainability of projects cannot be dismissed easily for example, Oni, Oladele \& Oyewole (2005), reported that literate farmers are likely to accept new innovation than illiterate farmers. Table 1 show that the majority $42 \%$ of the respondents had formal education up to high school level, $33 \%$ had tertiary education while $25 \%$ had 
S. Afr. J. Agric. Ext.

Vol. 44, No. 2, 2016: 30 - 41

DOI: http://dx.doi.org/10.17159/2413-3221/2016/v44n2a377
Manenzhe, Zwane

\& van Niekerk.

(Copyright)

primary school level of education. Formal education should not be taken in isolation to be capable of promoting sustainability, but can be argued that once literate farmers adopt technology this may enhance productivity hence greater farm returns.

\subsection{Challenges land reform beneficiaries faces towards sustaining their projects in Ehlanzeni District Municipality.}

\subsubsection{Marketing of produce}

Any farming venture aims at bringing income to the owner. A farming enterprise that fails to meet this objective will not survive for a long period. Figure 1 indicate that $16.7 \%$ of the respondents is involved in marketing of farm produce, $16.7 \%$ is managing production, $8.3 \%$ is managing farm finances, $50 \%$ manages the farm, other project activity the respondents are involved is bookkeeping which is $8.3 \%$. The writers have doubts whether the small percentage involved in marketing is sufficient to encourage sustainability. It was discovered during the study that some of the respondents are involved in other activities such as formal employment.

\subsubsection{Government support}

Anderson \& Feder (2003) identified the State as the agency with the most likely opportunity to help land reform beneficiaries overcome farming challenges and ensure sustainability on their projects. The study revealed that most of the respondents (75\%) felt there is a lack of government support. With such a high figure, one wonders as to whether the government will provide support in order to ensure sustainability. On the other hand too much government support may be seen as negative by attacking the very foundation of sustainability because one can argue that the government should never create dependency.

\subsubsection{Full time farming versus part time}

People go to farming for a variety of reasons, for example, Giles \& Stansfield (1987) observed that a person can resort to farming for the love of farming, or as an alternative to counteract their loneliness, counterbalance boredom, clearly providing a very form of part time employment to intensify their formal employment and as a recreational outlet. The findings revealed that participants spend inadequate time in their projects. It can be argued that where farming is not seen as full time the respondents will find sustainability a challenge.

\subsubsection{Resolving Farming challenges}

Farming involves a great deal of challenges that varies from farmer to farmer. Even established commercial farmers experience challenges in their farming ventures (Makhura, Mda, Marais, \& Jacobs, 2011). Resolving farming challenges is an essential tool for farmers to anticipate, avoid and react to shocks. Standard Bank Agribusiness (2013) noted that an efficient challenge resolution system for farming will preserve the standard of living of those who depend on farming, strengthen the viability of farm business and provide an environment that supports investment in the farming sector. The respondents' challenges are indicated in Figure 1. 
S. Afr. J. Agric. Ext.

Vol. 44, No. 2, 2016: $30-41$

DOI: http://dx.doi.org/10.17159/2413-3221/2016/v44n2a377
Manenzhe, Zwane

$\&$ van Niekerk.

(Copyright)

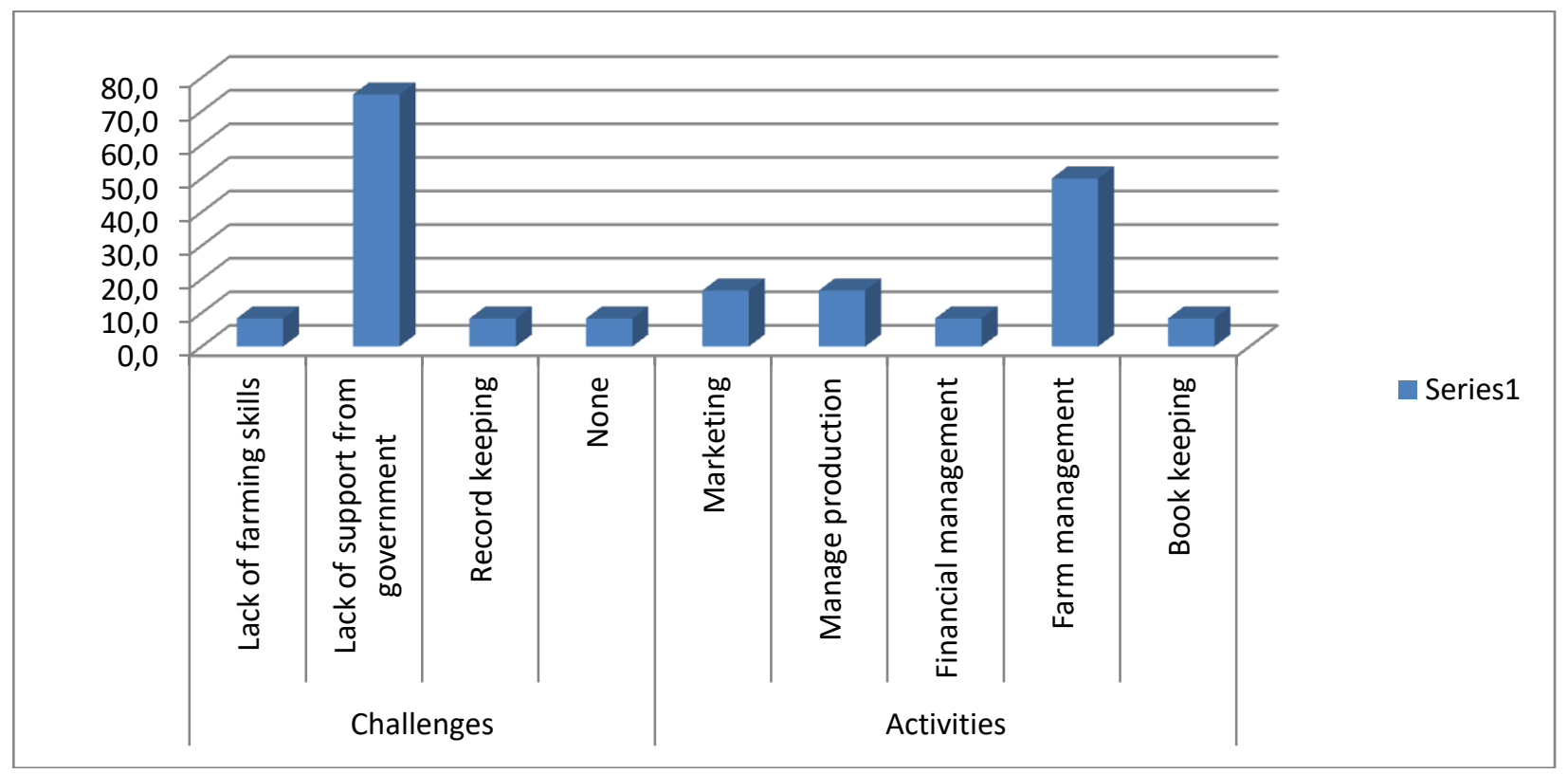

Figure 1: Respondents' farming challenges and roles

Resolving farming challenges requires skills and experiences. The very nature of participants' skills base and experience, which is sometimes not adequate, means that challenges resolution will to a certain extent at least, be subjective. It is not surprising that participants found it difficult to settle in. Feelings of beneficiaries on agricultural training attributes towards the sustainability of their projects are shown in Figure 2. The results shown in Figure 2 indicate that $75 \%$ of the respondents reported that they received agricultural training, whereas $25 \%$ indicated otherwise, signifying that majority of respondents received training to ensure project sustainability. In the findings of the study, the results show that, state was the main financier of agricultural training to the respondents $(83 \%)$ followed by unidentified financier (17\%). The figure further shows that $100 \%$ of respondents were willing to participate in agricultural training in future.

\subsubsection{Agricultural training}

According to Jacobs (2003), farmer training is critical for the viability and sustainability of agricultural projects. For instances, it is one of the methods in which one is sure that it will capacitate the farmers to be skilled. It also prepares farmers to make productive contributions. The study indicated that $75 \%$ of the respondents reported that they received agricultural training, whereas $25 \%$ indicated otherwise, signifying that majority of respondents received training to ensure project sustainability. It can be indicated that agricultural training can improve project sustainability.

\subsubsection{Participation in agricultural training}

Farmers' participation in training is considered necessary for the viability and sustainability of agricultural projects (Jacobs, 2003). As project performance is one of prerequisites when craving for project sustainability, Mmbengwa (2009) noted that small scale farming enterprises perform extremely poorly with regard to lack of input sources, sustainable markets and sustainable production. The respondents' perceptions are reflected in Figure 2. 


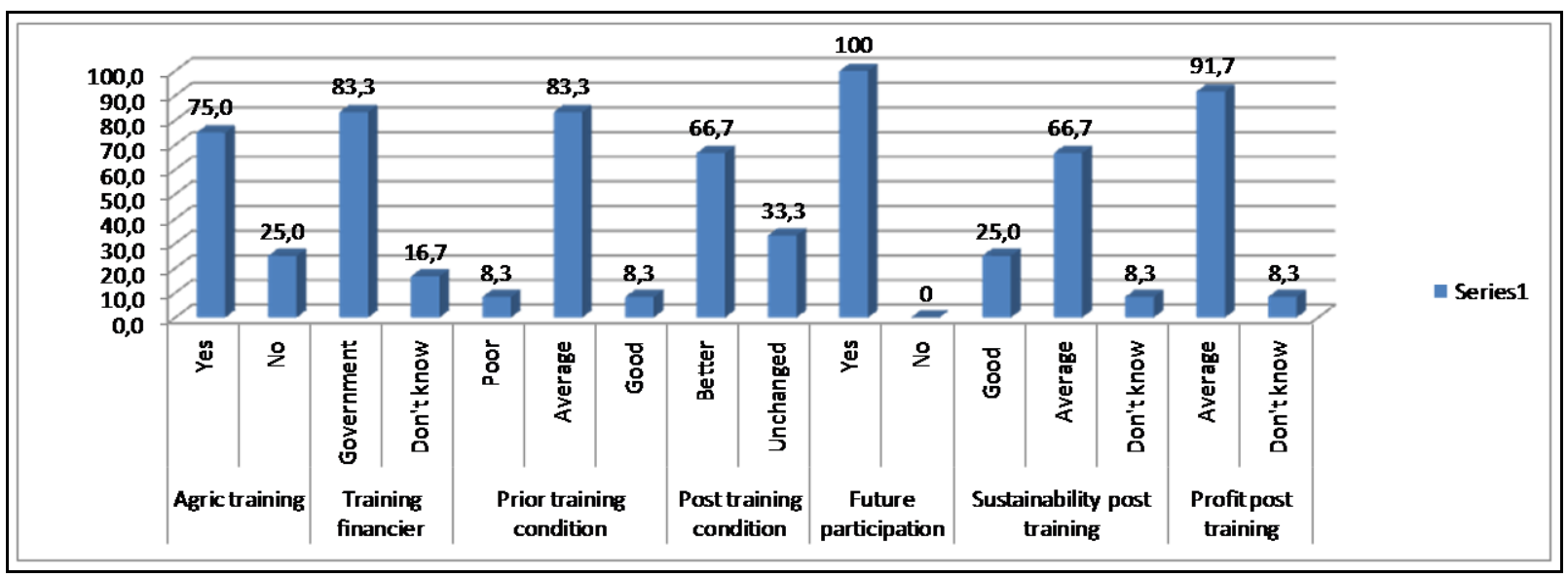

Figure 2: Beneficiaries' feelings on agricultural training attributes towards the sustainability of their projects

Figure 2 indicates that $83 \%$ of beneficiaries showed that project condition was average prior training and has a positive feeling that participation in agricultural training improved project condition; hence Recapitalization and Development Programme (RADP) where land reform project's sustainability is ensured by providing capacity building programme within land reform projects and agricultural projects owned- by emerging black farmers. About $67 \%$ of beneficiaries reported that participation in agricultural training has enhanced projects performance to a better state. The most outstanding feeling is that agricultural training improved project sustainability (67\%), training enhanced job creation $(58 \%)$ and training boosted projects profitability $(92 \%)$.

\subsection{Factors affecting sustainability of land reform projects in Ehlanzeni District Municipality}

The results in Table 2 shows that top down approach (92\%), barriers to access training on time $(75 \%)$ and complicated bureaucratic processes and procedures (67\%) are highly significant. The results imply that these factors contribute towards the projects productivity and, therefore, will affect the sustainability of land reform projects. This concurred with Taoana (2008), who found that land reform projects in the Western Cape often failed because the skills of the beneficiaries were not upgraded in time.

\subsubsection{Systematic approach for training of participants}

Effectively addressing the question of farmers access to appropriate training requires comprehensive knowledge of the constrains, needs and priorities of the particular farming project. According to Collett \& Gale (2009) there is a growing awareness that providing relevant training aiming to benefit farmers requires systematic efforts to engage with farmers and assess their circumstances.

Many different institutions adhere largely to an application-based or demand led approach to provide training. This means that beneficiaries who need training have to approach project officers or extension officers working for Provincial Department of Agriculture (PDoA). Jacobs (2003) observed that an application based approached transfers responsibility for agricultural development programme support from state to resource poor participants. Where 
S. Afr. J. Agric. Ext.

Vol. 44, No. 2, 2016: 30 - 41

DOI: http://dx.doi.org/10.17159/2413-3221/2016/v44n2a377
Manenzhe, Zwane

\& van Niekerk.

(Copyright)

this approach had been applied, it has been suggested it unnecessarily duplicates efforts invested in preparing business plans during project planning phase. In the study, it was found that the training was provided through top down approach where it should have been based on participant's needs assessment.

\subsubsection{Challenges in accessing training on time}

It has been seen that agricultural training is vital to capacitate farmers to be skilled and improve productivity and livelihoods, and despite this fact, land reform beneficiaries continues to receive training long after acquiring their project (Jacobs, 2003). Wallace, Mulhall, and Taylor (1996) detected that a serious challenge is that, training that is provided long after the project is acquired only means that beneficiaries have to play catch-up while already being embroiled in the day to day farming challenges. In the study, it was discovered that $75 \%$ of the participants received training long after acquiring their projects.

\subsubsection{Accessibility of training programme}

It is believed that easy access to quality government services will improve business sustainability. The Batho Pele programme of the Public Service (2010) summarised that systems, attitudes, procedures, and behaviour in public service sector will be enhanced to increase access to all facilities in public service to meet the needs of customers. The feeling from the majority of participants $(67 \%)$ is that process and procedures to access training were complicated.

It was a surprising matter when the majority of respondents indicated complicated bureaucracy in accessing agricultural training in this regard. Whereas Jacobs (2003) and Department of Agriculture (DoA) (2003) observed that it is a general knowledge that previously disadvantaged communities continue to have poor access to quality agricultural training as a result of various barriers including affordability, admission requirements, physical distance from training centres, literacy and numeracy, language of instruction and scant resources available to those charged with the responsibility of providing these training to these communities. The most important question is if government, through its Batho Pele programme is rising to the occasion of rendering easier and expanded access to services and continuous improvement in business practices.

\subsubsection{Post training support}

Post training support is seen as vital and critical in all land and agrarian reform processes, as can be told from experiences worldwide (Hoaës, 2010). Its absence or presence can have a number of consequences or successes in the whole process. Post training support can be viewed as the "after care" to be provided by government to beneficiaries who has been trained. It could be in the form of financial support as well as extension services. Turner and Ibsen (2000) find that land reform projects are failing to be sustainable because of the failure to provide adequate post training services. In the study, lack of post training support was statistically not significant (33\%) while $67 \%$ of participants reported to have been provided with post training support. This means that this factor has directly contributed towards project sustainability. This result shows that government is resorting to provide post training support to enhance sustainability of land reform projects. 
S. Afr. J. Agric. Ext.

Vol. 44, No. 2, 2016: 30 - 41

DOI: http://dx.doi.org/10.17159/2413-3221/2016/v44n2a377
Manenzhe, Zwane

\& van Niekerk.

(Copyright)

Table 2: Factors affecting sustainability of land reform projects in Ehlanzeni District Municipality

\begin{tabular}{|l|l|l|l|}
\hline \multirow{2}{*}{ Number } & Factors & \multicolumn{2}{|l|}{ Effect } \\
\hline & & Yes\% & No\% \\
\hline 1 & Delayed training & 72.0 & 25.0 \\
\hline 2 & Top down approach & 92.0 & 8.0 \\
\hline 3 & Lack of post training support & 33.0 & 67.0 \\
\hline 4 & Complicated bureaucratic process and procedures & 67.0 & 33.0 \\
\hline
\end{tabular}

\section{CONCLUSION}

Sustainable land reform projects are projects that are sustained in the medium or even longer term without continued external assistance, constantly growing net worth, consistently declining debt, farm enterprise is consistently profitable from year to year, production is increasing from season to season, reliance on government support is decreasing, project support other businesses and families in the community. To ensure sustainability of land reform projects, government and participant's mind-sets have to be refined. Government have to permit easy access to quality government services and participants should not treat farming as a part time endeavour to intensify their formal employment. The major factors affecting sustainability of land reform projects are lack of farming skills, lack of government support, participants resorting to farming on a temporary basis and participants' inability to resolve farming challenges on their own. The top down approach practiced in the department, participants' age, and participation in training has contributed a lot in sustainability of land reform projects. Inability to access training on time and complicated bureaucracy in accessing training reduces farmer possibilities of sustaining their project through training.

\section{EXTENSION IMPLICATIONS}

This study has shown that training of the project participants is a key factor in the success of the projects. Through training the performance and sustainability of the projects were improved. It also boosted the project profitability which in turn will have an effect on the income of the participants.

The study also pointed out the challenges of training, namely: timing of the training, approach (top down), support and accessibility of the training.

It is therefore important for extension officers involved in Land Reform projects to take note of these aspects. Training should be based on the needs of the project participants. The felt and unfelt needs should be determined before the training programme is formulated. The training should be at the right time when the participants need it.

\section{REFERENCES}

ANC (African National Congress). 1994. The Reconstruction and Development Programme: A policy framework. Johannesburg

ANDERSON, J., \& FEDER, G. 2003. Rural extension services. Washington DC: World Bank. (World Bank policy research working paper no. 2976) 
S. Afr. J. Agric. Ext.

Vol. 44, No. 2, 2016: 30 - 41

DOI: http://dx.doi.org/10.17159/2413-3221/2016/v44n2a377
Manenzhe, Zwane

\& van Niekerk.

(Copyright)

BULMER, M., \& WARWICK, D. 1983. Social Research in Developing Countries. New York: John Wiley \& Sons.

COLLETT, K., \& GALE, C. 2009. Training for rural development: Agricultural and enterprise skills for women smallholder. City \& Guildes, Centre for skills development, 24-30 West Smithfield, London.

DEPARTMENT OF AGRICULTURE (DoA). 2010. Agricultural training and education (AET) strategy for agriculture in rural in rural development in South Africa. Pretoria: DoA

DEPARTMENT OF AGRICULTURE, CONSERVATION AND ENVIRONMENT (DACE). 2003. Annual Report. South Africa

DEPARTMENT OF COOPERATIVE GOVERNANCE. 2010. Generic Batho Pele Generic Service Standards and Implementation Framework for Local Government. Republic of South Africa.

DEPARTMENT OF LAND AFFAIRS (DLA). 1997. White Paper on South African Land Policy. Pretoria: DLA.

DUMANSKI, J. (1994). Planning for sustainability in agricultural development projects. Centre for Land and Biological Resources Research. Agriculture and Agri-Food, Ottawa, Canada. $\mathrm{p} 15$.

EDM. (Ehlanzeni District Municipality). 2014. About Ehlanzeni District Municipality.

[Online]. Available http://www.ehlanzeni.co.za/background.html. [2015, July 07].

ERASMUS, D. 2015. ANC calls for land ceilings. Proposals to cap farmland ownership enact expropriation legislation and ban foreigners from owning land have been criticised as unfeasible and off putting to investors. Farmers weekly, 13 February 2015: 15.

GILES, T., \& STANSFIELD. M. 1987. The farmer as manager: Institute of Agricultural Management and Farm Management Unit, University of reading.

GREENBERG, S. 2003. Redistribution and access in a market-driven economy. Development Update, 4(2).

GIOVANNUCCI, D., SCHERR, S., NIERENBERG, D., HEBEBRAND, C., SHAPIRO, J., MILDER, J., \& WHEELER, K. 2012. Food and Agriculture: the future of sustainability. A strategic input to the Sustainable Development in the $21^{\text {st }}$ Century (SD21) project. New York: United Nations Department of Economic and Social Affairs, Division for Sustainable Development.

HOAES, I. M. 2010. Does a post settlement support play a role in the success of land reform? Unpublished Master's thesis. Stellenbosch: University of Stellenbosch.

IFAD. 2006. ARRI issues note: Sustainability. International document. Rome.

IFAD. 2007. IFAD Strategic Framework 2007-2010. Rome.

JACOBS, P. 2003. Evaluating land and agrarian reform in South Africa: Support for agricultural development. Programme for Land and Agrarian Studies, University of the Western Cape. (An Occasional Paper Series)

MAKHURA, M. N., MDA, M., MARAIS, P. \& JACOBS, J. 2011. Addressing challenges of addressing emerging farmers. Land Bank Report: Pretoria.

MMBENGWA, M. V. 2009. Capacity building strategies for sustainable farming SMMEs in South Africa: Dissertation, University of Free State.

NKWINTI, G. E. 2013. Speech by the Minister of Rural Development and Land Reform, debate on state of national address, on 23 February. Cape Town, Republic of South Africa.

OLADELE, O. I. 2011. Contribution of indigenous vegetables and fruits to poverty alleviation in Oyo State, Nigeria. J Hum Ecol, 34(1): 1-6 
S. Afr. J. Agric. Ext.

Vol. 44, No. 2, 2016: $30-41$

DOI: http://dx.doi.org/10.17159/2413-3221/2016/v44n2a377
Manenzhe, Zwane

\& van Niekerk.

(Copyright)

ONI, O. A., OLADELE, O. I., OYEWOLE, I. K. 2005. Analysis of factors influencing loan default among poultry farmers in Ogun State, Nigeria. J Central Europ Agric, 6(4): 619624.

SPARKS, A. 2003. Beyond the miracle: Inside the new South Africa. Cape Town: Jonathan Ball.

STANDARD BANK AGRIBUSINESS SA. 2013. Finance and Farm management. The Standard Bank of South Africa Limited. Johannesburg.

SUSTAINABILITY STORE (SS). 1999. What is sustainability? What does sustainability mean? [Online]. Available http://www.sustainabilitystore.com/about.htm [2015, September 27].

TAOANA, L. K. 2008. Land Reform and Livelihoods in Frances Baard District Northern Cape Province: Case study of Survive and Dikgoho Projects, Wageningen University, The Netherlands.

TURNER, S., \& IBSEN, H. 2000. Land Agrarian reform in South Africa: A status report. Cape Town: Programme for Land and Agrarian Studies, University of the Western Cape. (Research report; no. 6)

VAN REENEN, M. J., \& MARAIS A DE K. 2013. Farm management. Financial Planning, Analysis and Control.

WALLACE, I., MULHALL, A., \& TAYLOR, P., 1996. Developing a Research Framework for Improved Policies for Agricultural Education and Training in sub- Saharan Africa. Report of an International Consultation held at Reading, United Kingdom, 20-21 March 1996. Reading, United Kingdom, Agricultural Extension and Rural Development Department, University of Reading.

WORLD COMMISSION ON ENVIRONMENTAL AND DEVELOPMENT (WCED). 1987. Our Common Future. Report of World Commission on Environment and Development. New Delhi: Oxford University Press. 